\title{
Akut koroner sendrom hastalarında serum kalsiyum düzeyinin hastane içi ve uzun dönem mortalite ile ilişkisi
}

\author{
The association of serum calcium levels with in-hospital and long-term mortality in \\ patients with acute coronary syndrome
}

\author{
Gökhan Sönmez, Dursun Dursunoğlu, Mehmet Koray Adalı
}

Gönderilme tarihi:03.11.2021

Kabul tarihi:21.01.2022

Öz

Amaç: Serum kalsiyum düzeyinin kardiyovasküler risk faktörleri ve koroner arter hastalığı (KAH) ile ilişkisi iyi bilinmektedir. Ancak kalsiyumun, KAH olan hastalarda sağ kalım üzerine etkisi yeterince değerlendirilmemiştir. Biz bu çalışmada, kalsiyumun akut koroner Sendrom (AKS) sonrası hastane içi ve bir yıllık takipte mortalite üzerindeki rolünü araştırmayı amaçladık.

Gereç ve yöntem: Bu prospektif gözlemsel çalışmaya AKS nedeniyle koroner anjiyografisi yapılan 90 hasta dahil edildi. Hastalar albümin baz alınarak hesaplanan düzeltilmiş serum kalsiyum düzeylerine göre sınıflandırıldı. Çalışmada, hastane içi ölüm ve kardiyak nedenli komplikasyonlar birincil sonlanım, bir yıl içerisinde tüm nedenlere bağlı ölümler ikincil sonlanım olarak tanımlandı. Serum kalsiyum düzeyi ile mortalite arasındaki ilişki lojistik regresyon analiziyle değerlendirildi.

Bulgular: Başlangıç analizlerinde serum kalsiyum düzeyleri, hastane içi dönemde ve takip döneminde mortalite ile ilişkili değildi. Ancak lojistik regresyon analizinde AKS hastalarında başvuru kalsiyum düzeyleri ile hastane içi mortalite arasında anlamlı bir ilişki saptanamazken, düşük kalsiyum düzeyi bir ay içinde gerçekleşen tüm nedenlere bağlı ölümler için önemli bir risk faktörüydü ( $p=0,038, \mathrm{OR}=7,387, \% 95 \mathrm{Cl}=1,121-48,664)$. Serum kardiyak troponin ve ürik asit düzeyleri ise, hastane içi mortalite ile anlamlı ilişki gösterdi (sırasıyla $p=0,018$, OR=1,206, \%95 Cl=1,033-1,408; $p=0,014$, OR=1,377, \%95 Cl=1,067-1,776).

Sonuç: Serum kalsiyum düzey düşüklüğü, AKS sonrası hastane içi mortaliteyle ilişkili değildir; ancak ilk bir ay içinde gerçekleşen tüm nedenlere bağlı mortalite oranını artırabilir.

Anahtar kelimeler: Akut koroner sendrom, kalsiyum, aterosklerozis.

Sönmez G, Dursunoğlu D, Adalı MK. Akut koroner sendrom hastalarında serum kalsiyum düzeyinin hastane içi ve uzun dönem mortalite ile ilişkisi. Pam Tıp Derg 2022;15:267-275.

\begin{abstract}
Objective: The relationship between serum calcium levels with cardiovascular risk factors and coronary artery disease (CAD) is well known. However, the effect of calcium on survival in patients with CAD has not been adequately evaluated. In this study, we aimed to investigate the role of calcium on mortality in the hospital and one-year follow-up after acute coronary syndrome (ACS).

Materials and methods: 90 patients who underwent coronary angiography for ACS were included in this prospective observational study. Patients were classified according to their corrected serum calcium levels calculated based on albumin. In-hospital mortality and cardiac complications were defined as the primary outcome, and all-cause mortality within one year was defined as the secondary outcome in the study. The relationship between serum calcium level and mortality was evaluated by logistic regression analysis.

Results: In the initial analysis, serum calcium levels were not associated with in-hospital mortality and followup period. However, in logistic regression analysis, no significant relationship was found between admission calcium levels and in-hospital mortality in ACS patients, while low calcium levels were an important risk factor for all-cause mortality within one month $(p=0.038, \mathrm{OR}=7.387,95 \% \mathrm{Cl}=1.121-48.664)$. Serum cardiac troponin and uric acid levels showed a significant association with in-hospital mortality $(p=0.018, \mathrm{OR}=1.206,95 \% \mathrm{Cl}=1.033$ 1.408, $p=0.014, \mathrm{OR}=1.377,95 \% \mathrm{Cl}=1.067-1.776$, respectively).

Conclusion: Low serum calcium levels are not associated with in-hospital mortality after ACS. However, it may increase all-cause mortality rate in the first month.
\end{abstract}

Key words: Acute coronary syndrome, calcium, atherosclerosis.

Sonmez G, Dursunoglu D, Adali MK. The association of serum calcium levels with in-hospital and long-term mortality in patients with acute coronary syndrome. Pam Med J 2022;15:267-275.

Gökhan Sönmez, Uzm. Dr. Tavşanlı Doç. Dr. Mustafa Kalemli Devlet Hastanesi, Kardiyoloji Kliniği, Kütahya, Türkiye, e-posta: drgs2020@gmail. com (https://orcid.org/0000-0002-6450-3091) (Sorumlu Yazar)

Dursun Dursunoğlu, Prof. Dr. Pamukkale Üniversitesi Tıp Fakültesi, Kardiyoloji Anabilim Dalı, Denizli, Türkiye, e-posta: ddursunoglu@gmail. com (https://orcid.org/0000-0002-5232-7078)

Mehmet Koray Adalı, Dr. Öğr. Üye. Üniversitesi Tıp Fakültesi, Kardiyoloji Anabilim Dalı, Denizli, Türkiye, e-posta: korayadali@gmail.com (https:// orcid.org/0000-0002-0054-6252) 


\section{Giriş}

Akut koroner sendrom (AKS) stabil olmayan anjina pektoris (USAP), ST-yükselmesiz miyokard enfarktüsü (STYzMi) ve STyükselmeli miyokard enfarktüsüyle (STYMi) temsil edilen kompleks bir sendromdur ve koroner arterdeki aterosklerozun ilerlemesine bağlı olarak çeşitli klinik prezentasyonlara yol açabilir [1]. AKS, perkütan koroner girişim (PKG) ve konvansiyonel tedavideki ilerlemelere rağmen hala kötü prognoz ile ilişkilidir. Bu nedenle erken risk sınıflandırılması ve doğru tedavi stratejilerinin belirlenebilmesi oldukça önemlidir [2].

İskelet dışı kalsiyum miyokard kasılması, trombosit adhezyonu, koagülasyon, kardiyomiyosit apoptozu ve kalbin elektrofizyolojisi gibi kalbi ilgilendiren birçok biyofizyolojik süreçte kritik bir öneme sahiptir $[3,4]$. Serum kalsiyum düzeyinin hipertansiyon, dislipidemi, diyabet, sigara ve obezite gibi kardiyovasküler risk faktörleriyle ilişkili olduğu bilinmektedir [5]. Ayrıca serum kalsiyum düzeyinin koroner arter hastalığı (KAH) varlığı, kardiyovasküler, ve kardiyovasküler olmayan tüm nedenli ölümler için bağımsız bir prediktör olabileceği çeşitli çalışmalarda bildirilmiştir [4, $6,7]$. Çalışma raporlarına göre serum kalsiyum düzeyinin ölçümü ve seri takipleri $\mathrm{KAH}$ varlığını ve prognozu gösteren bir belirteç olabilir [6, 7]. Ancak bu konudaki çalışmalar, çoğu kez gerçek yaşam verilerini içermeyip, genellikle seçilmiş hasta gruplarında yapılmıştır. Bu nedenle biz bu çalışmada AKS hastalarındaki başvuru anında ölçülen serum kalsiyum düzeyi ile hastane içi ve bir yıllık mortalite arasındaki ilişkiyi gerçek yaşam verileri ile değerlendirmeyi amaçladık.

\section{Gereç ve yöntem}

$\mathrm{Bu}$ prospektif gözlemsel çalışma, Ocak 2017- Aralık 2017 tarihleri arasında AKS nedeniyle Pamukkale Üniversitesi Tıp Fakültesi hastanesine başvuran ve koroner anjiyografisi yapılan 90 hastayla gerçekleştirildi. Malignite, akut veya kronik enfeksiyon, otoimmun hastalıklar, ciddi hematolojik bozukluklar, aktif kanama, akut perikardit, akut miyokardit, vazospastik anjina, koroner anomaliler, ciddi karaciğer hastalığı ve gebelik çalışmanın dışlama kriterleri olarak tanımlandı.

$\mathrm{Bu}$ çalışma Helsinki Bildirgesi'ne uygun olarak Pamukkale Üniversitesi Tıp Fakültesi,
Girişimsel Olmayan Klinik Araştırmalar Etik Kurulu tarafından onaylandı (2017/2-020/8889) ve tüm kayıtı hastalardan bilgilendirilmiş onam formu alındı.

\section{Veri toplanması ve tanımlamalar}

Çalışmaya dahil edilen hastaların yaş, cinsiyet, sigara kullanımı, kardiyovasküler risk faktörleri, komorbidite ve ilaç kullanımını içeren demografik ve klinik verileri kaydedildi. Tüm katılımcıların detaylı fizik muayeneleri yapıldı. Hastalardan başvuru anında ve 8-12 saat açlık sonrası serum kalsiyum, açlık glukozu, kreatinin, lipid paneli ve tam kan sayımı gibi standart laboratuvar parametrelerini değerlendirmek için periferik venöz kan örnekleri toplandı. Biyokimyasal parametreler Cobas 8000 otoanaliz (Roche Diagnostic Corp., Mannheim, Germany) cihazıyla, tam kam sayımı Mindray BC-6800 otoanaliz (Mindray Bio-Medical Electronics Co., Ltd., Shenzhen, China) cihazıyla analiz edildi. Düzeltilmiş serum kalsiyum düzeyi Payne formülü kullanılarak hesaplandı (Düzetilmiş $\mathrm{Ca}(\mathrm{dCa})=$ Serum $\mathrm{Ca}+$ $0,8 \times[(4,0$-albümin $)])[8]$.

Transtorasik ekokardiyografi sol lateral dekubitis pozisyonda GE VIVID 7, GE VIVID 5, Philips Purewave S5-1 cihazları kullanılarak yapıldı. Ekokardiyografide sol ventrikülün morfolojik yapısı değerlendirildi ve sol ventrikül ejeksiyon fraksiyonu (SVEF) modifiye bi-planar Simpson metodu kullanılarak hesaplandı. Koroner anjiyografi, sağ femoral yoldan Judgkins tekniğiyle yapıldı. Anjiyografik görüntüler çalışma protokolüne kör olan en az iki deneyimli klinisyen tarafından rastgele analiz edildi.

AKS tanısı, Avrupa Kardiyoloji Derneği (ESC) kılavuzları baz alınarak konuldu [9, 10]. En az bir epikardiyal damarda \%50 ve üzerinde darlık bulunması, anlamlı KAH olarak kabul edildi. Hipertansiyon, sistolik kan basıncı $140 \mathrm{mmHg}$ veya diyastolik kan basıncı $90 \mathrm{mmHg}$ veya tıbbi tedavi alıyor olmak şeklinde tanımlandı. Diyabet, açlık kan şekeri $>126 \mathrm{mg} / \mathrm{dL}$ veya herhangi bir zamanda kan şekeri $\geq 200 \mathrm{mg} / \mathrm{dL}$ olması veya antidiyabetik ilaç kullanımı olarak tanımlandı. Hiperlipidemi, Ulusal Kolesterol Eğitim Programı-3'ün önerilerine göre artmış düşük yoğunluklu lipoprotein kolesterol (LDL-K) düzeyi veya lipid düşürücü ilaç kullanımı olarak tanımlandı. 


\section{Klinik sonlanım}

Hastalar bir yıl boyunca tüm nedenlere bağlı ölümler (kardiyak, nonkardiyak) açısından takip edildi ve poliklinik vizitlerinde hastalar tekrarlayan klinik değerlendirmelere tabi tutuldu. Çalışmanın birincil sonlanımı hastane içi tüm nedenlere bağlı ölümler ve hastane içi kardiyak komplikasyonlar, ikincil sonlanımı ise AKS sonrası ilk bir yıl içinde tüm nedenlere bağlı ölümler olarak kabul edildi.

\section{İstatiksel analiz}

Kategorik değişkenler frekans ve yüzde ile sürekli değişkenler ortalama \pm SS ile ifade edildi. Değişkenlerin normal dağılımını belirlemede Kolmogorov-Smirnov testi kullanıldı. Bağımsız grup karşılaştırmalarında Independent samples $t$ testi ve Mann-Whitney $U$ testi kullanıldı. Kategorik değişkenlerin karşılaştırması $X^{2}$ testi kullanılarak gerçekleştirildi. AKS hastalarında mortaliteyi etkileyen risk faktörlerinin belirlenmesinde lojistik regresyon analizi kullanıldı. Hastaların ilk yatıştaki mortalite durumu ile ilk geliş dCa arasında tek faktörlü regresyon analizi, hastaların mortalite durumu ile taburculuk dCa arasında tek faktörlü regresyon analizi, hastaların ilk yatıştaki mortalite durumu ile ilk geliş troponin arasında tek faktörlü regresyon analizi, hastaların ilk yatıştaki hastane içi mortalite durumu ile ilk geliş ürik asit değeri arasında tek faktörlü regresyon analizi yapıldı ve $p<0,05$ istatistiksel olarak anlamlı kabul edildi.

\section{Bulgular}

Çalışma popülasyonunun klinik özellikleri Tablo 1'de gösterilmiştir. Başvuruda alınan serum örneklerindeki kalsiyum düzeylerine göre hastalar dört gruba ayrılmıştır. Yaş, cinsiyet ve aktif sigara kullanımı gruplar arasında benzerdi. Hipertansiyon dışında diyabet, kronik böbrek yetersizliği ve kronik pulmoner hastalık gibi ek hastalık insidanslarında anlamlı farklılık yoktu. PKG ya da koroner arter baypas greftleme (KABG) yöntemleri ile yapılan revaskülarizasyon oranları benzerdi. ( $p>0,05)$ Açlık glukozu, kreatinin, total kolesterol, trigliserid, LDL-K, yüksek yoğunluklu lipoprotein kolesterol (HDL-K), troponin, ürik asit ve tam kan sayımını içeren standart laboratuvar parametreleri gruplar arasında anlamlı farklılık göstermedi $(p>0,05)$.
Başvuru sırasında alınan serum örneğindeki kalsiyum düzeyine göre hastalar hipokalsemik, normokalsemik ve hiperkalsemik olarak üç grupta katerogize edildi. Fakat hiperkalsemik grupta hiç hasta yoktu. Grupların hastane içi klinik sonlanımları Tablo 2'de gösterilmektedir. Hipokalsemik hastaların \%59'u STYMI, \%32'si STYzMi ve \%9'u USAP; normokalsemik hastaların ise \%46'sı STYMi, \%37'si STYzMi, \%18'si USAP tablosuyla başvurdu ve gruplar arası klinik bulgular anlamlı farklılık göstermedi $(p=0,468)$. Gruplar arasında hastane içi ve ilk 6 aylık sağkalımı gösteren GRACE skoru, çok damar hastalığı ve ana korumasız sol ana koroner arter hastalığı ile tanımlanan $\mathrm{KAH}$ ciddiyeti, hastane kalış süresi, SVEF ve hastane içi kardiyak komplikasyon oranı benzerdi. Hipokalsemik ve normokalsemik hastaların hastane içi mortalite oranları sırasıyla $\% 23$ ve \%14 idi ve anlamlı istatiksel fark yoktu $(p=0,332)$. Bir yıllık takipte grupların 1., 6. ve 12 . ay hastaneye tekrar yatış ve revaskülarizasyon oranları da anlamlı farklılık göstermedi. Hipokalsemik hastalarda ilk bir ay içinde tüm nedenlere bağlı ölümler \%12 oranında, normoklasemik hastalarda \%20 oranında görüldü $(p=0,746)$. Tüm gruplarda 6 . ve 12 . ay takiplerinde kardiyak ya da nonkardiyak nedenlere bağlı ölüm gerçekleşmemekle birlikte, grupların rehospitalizasyon ve revaskülarizasyon oranları benzerdi (Tablo 3). Lojistik regresyon analizinde başvuru esnasındaki kalsiyum düzeyinin hastane içi mortaliteyi etkilemediği; ancak ilk 30 gün içi tüm nedenlere bağlı ölümlerde anlamlı bir risk faktörü olduğu saptandı ( $p=0,038$ OR=7,387, \%95 Cl=1,121-48,664) (Tablo 4). Ayrıca başvuru esnasındaki troponin ve ürik asit düzeyleri, 1 aylık mortalite üzerine etkili olmasa da (Tablo 4) bu iki parametre hastane içi mortalite için anlamlı risk faktörleriydi (sırasıyla $p=0,018, \mathrm{OR}=1,206$, \%95 Cl=1,033-1,40; $p=0,014, \mathrm{OR}=1,377, \% 95$ $\mathrm{Cl}=1,067-1,776)$.

\section{Tartışma}

Akut koroner sendrom hastalarında serum kalsiyum düzeyinin hastane içi mortalite ve kardiyak komplikasyonlar ile ilk bir yıl içindeki mortalite üzerindeki rolünü değerlendirmeyi amaçladığımız buçalışmamızda; hipokalseminin hem hastane içi ve hem de bir yıllık takipte mortaliteyi etkilemediği, ilk bir ay içindeki tüm nedenlere bağlı mortaliteyi artırdığı gösterildi. 


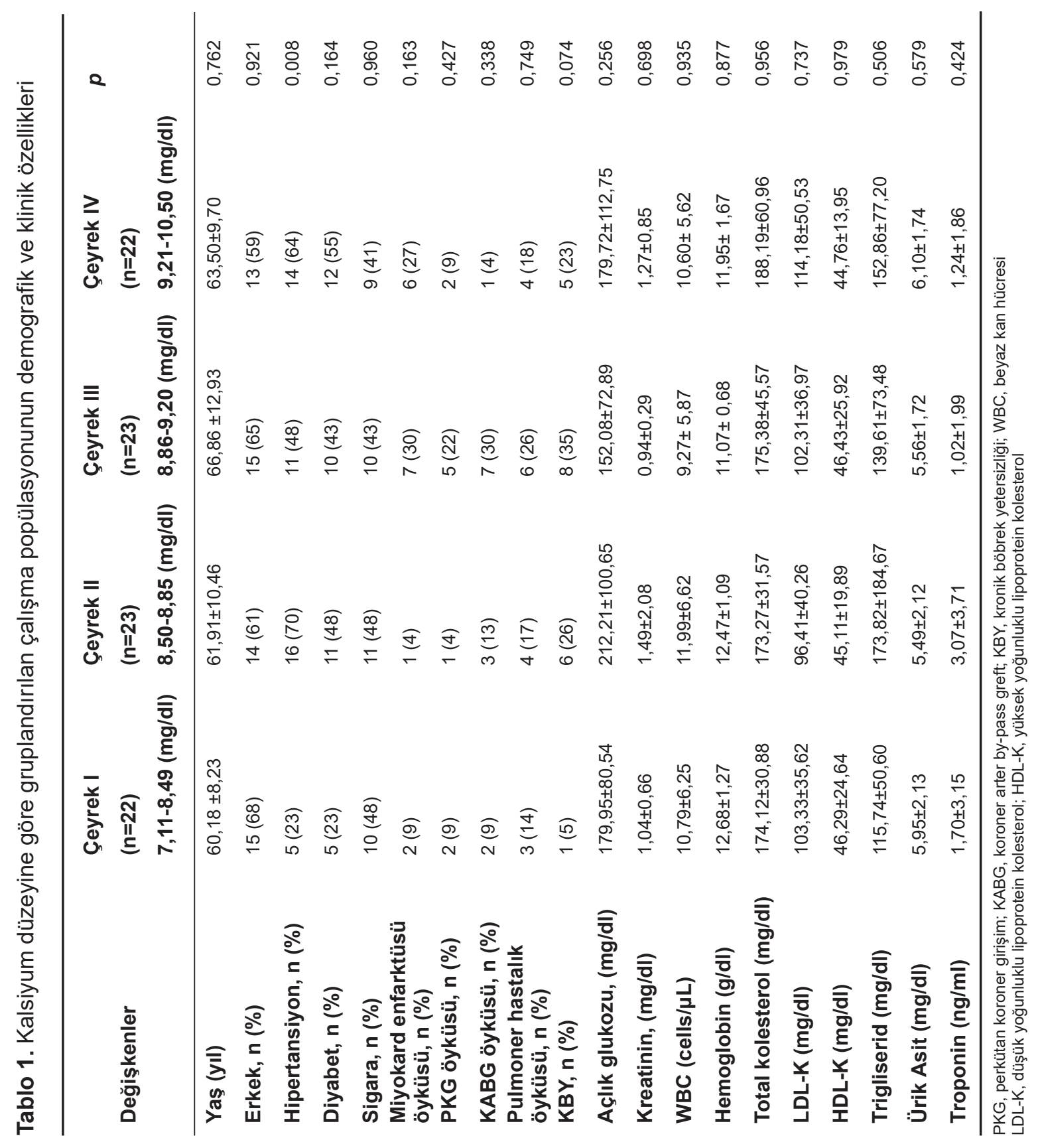


Tablo 2. Çalışma popülasyonunun hastane yatışı sırasındaki klinik verileri

\begin{tabular}{|c|c|c|c|}
\hline Değişkenler & $\begin{array}{l}\text { Hipokalsemik hastalar } \\
(\mathrm{n}=22) \\
<8,50(\mathrm{mg} / \mathrm{dl})\end{array}$ & $\begin{array}{l}\text { Normokalsemik hastalar } \\
(\mathrm{n}=68) \\
8,51-10,5(\mathrm{mg} / \mathrm{dl})\end{array}$ & $p$ \\
\hline STYMi, n (\%) & $13(59)$ & $31(46)$ & \\
\hline STYzMi, n (\%) & $7(32)$ & $25(37)$ & 0,468 \\
\hline USAP, n (\%) & $2(9)$ & $12(18)$ & \\
\hline GRACE score & $132,54 \pm 32,53$ & $133,32 \pm 30,30$ & 0,982 \\
\hline Sol ana koroner hastalığı, n (\%) & $1(5)$ & $9(13)$ & 0,187 \\
\hline Çok damar hastalığı, n (\%) & 12 & 41 & 0,052 \\
\hline Hastane yatış süresi (day) & $6(4-8)$ & $5(4-7)$ & 0,527 \\
\hline SVEF<35, n (\%) & $8(36)$ & $22(32)$ & \\
\hline $35<$ SVEF < 50, n (\%) & $7(32)$ & $22(32)$ & 0,954 \\
\hline SVEF> 50, n (\%) & $7(32)$ & $22(35)$ & \\
\hline Kardiyojenik şok, n (\%) & $1(5)$ & $2(3)$ & 0,689 \\
\hline Ciddi aritmi, n (\%) & $6(27)$ & $11(16)$ & 0,346 \\
\hline Tekrarlayan iskemi, $\mathbf{n}(\%)$ & - & - & - \\
\hline Hastane içi ölüm, n (\%) & $5(23)$ & $9(14)$ & 0,332 \\
\hline
\end{tabular}

STYMI, ST-yükselmeli miyokard enfarktüsü; STYzMi, ST-yükselmesiz miyokard enfarktüsü; USAP, stabil olmayan anjina pektoris SVEF, sol ventrikül ejeksiyon fraksiyonu

Tablo 3. Takip sırasında çalışma popülasyonunun klinik sonlanımları

\begin{tabular}{|c|c|c|c|}
\hline Değişkenler & $\begin{array}{l}\text { Hipokalsemik hastalar } \\
(\mathrm{n}=17) \\
<8,50(\mathrm{mg} / \mathrm{dl})\end{array}$ & $\begin{array}{l}\text { Normokalsemik hastalar } \\
(\mathrm{n}=59) \\
8,51-10,5(\mathrm{mg} / \mathrm{dl})\end{array}$ & $p$ \\
\hline \multicolumn{4}{|l|}{ 1.ay sonlanım noktası } \\
\hline Tekrarlayan yatış, n (\%) & $3(18)$ & $5(8)$ & 0,468 \\
\hline Revaskülarizasyon, n (\%) & - & $1(2)$ & 0,367 \\
\hline Ölüm, n (\%) & $2(12)$ & $12(20)$ & 0,746 \\
\hline \multicolumn{4}{|l|}{ 6. ay sonlanım noktası } \\
\hline Tekrarlayan yatış, n (\%) & $1(7)$ & $7(15)$ & 0,492 \\
\hline Revaskülarizasyon, n (\%) & $1(7)$ & $3(6)$ & 0,973 \\
\hline Ölüm, n (\%) & - & - & - \\
\hline \multicolumn{4}{|l|}{ 12.ay sonlanım noktası } \\
\hline Tekrarlayan yatış, n (\%) & $1(7)$ & $8(17)$ & 0,385 \\
\hline Revaskülarizasyon, n (\%) & - & $3(6)$ & 0,128 \\
\hline Ölüm, n (\%) & - & - & - \\
\hline
\end{tabular}


Tablo 4. Lojistik regresyon analizinde laboratuvar parametreleri ile mortalite arasındaki ilişki

\begin{tabular}{|c|c|c|c|c|c|c|}
\hline Değişkenler & Beta & SE $\beta$ & Wald's $x^{2}$ & $p$ & OR & $95 \% \mathrm{Cl}$ \\
\hline \multicolumn{7}{|l|}{ Hastane içi ölüm } \\
\hline Başlangıç kalsiyum düzeyi & 0,521 & 0,415 & 1,577 & 0,209 & 1,684 & $0,747-3,798$ \\
\hline Başlangıç kardiyak troponin düzeyi & 0,187 & 0,079 & 5,621 & $0,018^{*}$ & 1,206 & $1,033-1,408$ \\
\hline Başlangıç ürik asit düzeyi & 0,320 & 0,130 & 6,048 & $0,014^{*}$ & 1,377 & $1,067-1,776$ \\
\hline \multicolumn{7}{|l|}{ Birinci ay ölüm } \\
\hline Başlangıç kalsiyum düzeyi & 2,00 & 0,962 & 4,322 & $0,038^{*}$ & 7,387 & $1,121-48,664$ \\
\hline Başlangıç kardiyak troponin düzeyi & 0,213 & 0,137 & 2,425 & 0,119 & 1,237 & $0,946-1,618$ \\
\hline Başlangıç ürik asit düzeyi & 0,461 & 0,266 & 3,012 & 0,083 & 1,586 & $0,942-2,668$ \\
\hline
\end{tabular}

Serum kalsiyum düzeyi ile $\mathrm{KAH}$ prognozu arasındaki ilişki, çeşitli çalışmalara konu olmuştur [6, 7]. Kalsiyumun serum düzeylerinin azalmasının, 'stabil' KAH olan hastalarda bir yıllık takipte mortaliteyi belirgin olarak etkilemediği gösterilmiştir [11]. Serum kalsiyum düzeyinin azalmasının, özellikle kritik hastalarda olmak üzere mortaliteyi artırdığı bazı çalışmalarda gösterilmiştir [12, 13]. Altta yatan mekanizmalar yeterince aydınlatılamasa da çeşitli hipotezlerle kalsiyumun AKS üzerindeki rolü açıklanmaya çalışılmaktadır. Bunlardan bazıları hipokalseminin kardiyovasküler risk faktörleriyle ilişkili olabileceği, kardiyomiyositlerde plato fazını uzatıp aritmilere neden olması, miyokard kontraktilitesini bozması, hücre içi kalsiyum artışına bağlı toksisite artışı ile miyositlerde apopotoza yol açması, damar kalsifikasyonuna neden olması, endotelyal ve platelet aktivasyonunu bozarak trombogenezi tetiklemesi, lipid birikimine ve enflamasyona yol açmasıdır [14]. Lu ve ark. [15], 1431 STYMi hastasını içeren çalışmasında serum kalsiyum düzeyi düşüklüğünün hastane içi mortalite için bağımsız bir ön gördürücü olduğunu göstermişlerdir. Ancak bizim çalışmamızda, serum kalsiyum düzeyi düşük ve normal olan hastalar arasında hasta içi mortalite oranları arasında hem başlangıç hem de ileri analizlerde anlamlı bir fark saptanmadı. Nitekim Lu ve ark. [15] çalışmalarına daha yaşlı katılımcıları dahil ettiler ve çalışma popülasyonlarındaki hastaların kardiyovasküler risk profilleri daha kötüydü ve ek hastalık insidansları bizim çalışmamıza göre daha yüksekti. Ayrıca çalışmalarında yüksek TIMI risk skoruna sahip ve Killip III sınıfına tabi hasta oranı yüksekti ve erken revaskülarizasyon oranları da düşüktü. Bizim çalışmamızda ise prognozu gösteren TIMI risk skoru yerine GRACE risk skoru kullanıldı. Çalışmamızda grupların GRACE risk skorları arasında anlamlı farklılık yoktu ve grupların yaş ortalamaları ve klinik özellikleri, Lu ve ark.'nın [15] çalışmasının aksine, benzerdi. Başka bir çalışmada ise, kalsiyumun hem düşük hem de yüksek düzeylerinin hastane içi mortaliteyi artırdığı ve kalsiyum ile mortalite arasındaki ilişkinin $U$ şeklinde olduğu gösterilmiştir. Bu çalışmaya göre serum kalsiyum düzeyi <8,90 $\mathrm{mg} / \mathrm{dl}$ ve $>9,86 \mathrm{mg} / \mathrm{dl}$ olması, mortalite artışı ile ilişkilidir [14]. Bizim çalışmamızda ise serum kalsiyumun normal düzeyleri, 8,50-10,50 mg/ dl arasında kabul edilmiştir. Bu çalışmaya göre normokalsemi grubunda 8,50-8,90 mg/dl ve 9,86-10,50 mg/dl kalsiyum düzeylerine sahip hastalarımızın mortalite oranı artmaktadır ve bu çalışmanın sonuçları gruplarımızdaki benzer hastane içi mortalite oranını açıklayabilir.

Kalsiyum takviyesinin yararları hakkındaki çalışmalar çelişkili olsa da yeni yapılan bir çalışmada, özellikle yoğun bakım hastalarında kalsiyum takviyesinin kısa dönem prognozu ve sağkalımı olumlu yönde etkilediği gösterilmiştir $[16,17]$. Çalışmamızda serum kalsiyum düzeyi düşük hastalara kalsiyum takviyesi yapılmış olması, hipokalsemik hastaların normokalsemik hastalara benzer mortalite oranına sahip olmalarınıaçıklayabilir. AKS hastalarının hastane içi komplikasyonlarının kalsiyum düzeyi ilişkisini değerlendiren başka bir çalışmada, serum kalsiyum düzeyi $<8,3 \mathrm{mg} / \mathrm{dl}$ olan hastalarda kalp yetersizliği, atriyoventriküler blok, kontrast nefropatisi gibi komplikasyonlar anlamlı olarak daha yüksek bulunmuştur [18]. Ancak bizim 
çalışmamızda serum kalsiyum düşüklüğü ile hastane içi komplikasyon arasında herhangi bir ilişki saptanmadı. 192 STYMi hastasının dahil edildiği diğer bir çalışmada ise, serum kalsiyum düzeyi düşük ve normal hastalarda hastane içi benzer kardiyak komplikasyonlar görülmesi çalışmamızı destekler niteliktedir [19].

Çalışmamızda hastaların takibi sırasında başlangıç analizlerinde ilk 30 gün içindeki mortalite oranları serum kalsiyum düzeyiyle ilişkisiz görünse de lojistik regresyon analizinde, başvuru esnasındaki serum kalsiyum düşüklüğünün AKS sonrası ilk 30 gün içi tüm nedenlere bağlı mortaliteyi artıran bir faktör olduğu gösterilmiştir. 2594 AKS hastasının alındığı bir çalışmada, kalsiyum düzeyi orta vadede tüm nedenli ölümlerde bir $\mathrm{J}$ eğrisi göstermiştir ve bu eğriye göre serum kalsiyum düşüklüğü, çalışmamıza benzer şekilde, artan mortalite ile ilişkilendirilmiştir [20]. Çalışmamızda 6. ve 12 ay içinde hiç ölüm gerçekleşmediği için, orta ve uzun dönem sonlanım hakkında herhangi bir fikir verilmemiş olması doğaldır. Prospektif dizayn nedeniyle hastalarımızın sıkı takip edilmiş olması, optimal ilaç kullanımının sağlanması, tekrarlayan revaskülarizasyon işlemlerinin zamanında yapılması ve kalsiyum takviyesi, hastalarımızın uzun dönem (bir yıllık) iyi prognozunu açıklayabilir.

Çalışmamızda dikkat çeken diğer bulgular ise başvuru esnasındaki artmış kardiyak troponin ve ürik asit düzeylerinin hastane içi mortalite riskini anlamlı bir şekilde artırmasıydı. Bir çalışmada AKS hastalarında artmış (>6 mg/ dl) ürik asit düzeyleri, hastane içi mortaliteyi göstermede bağımsız bir risk faktörü olarak saptanmış olup çalışma sonuçlarımızla örtüşmektedir [21]. Başka bir çalışmada da uzun dönem sağkalım ile serum ürik asit düzeyleri arasında anlamlı bir korelasyon gösterilmiştir [22]. Ürik asit düzeyleri ile artmış hastane içi mortalite arasındaki ilişki, yüksek ürik asit seviyelerin, hipertansiyon [23, 24], diyabet [25], kronik böbrek yetersizliği [23, 26] ve hiperlipidemi gibi kardiyovaskuler risk faktörleri ile ilişkisi olmasından kaynaklanıyor olabilir. Çalışmamız, AKS hastalarımızda birinci aydan sonra ölüm olmaması nedeniyle, ürik asidin uzun dönem sağkalım üzerine etkisi hakkında bir fikir verememektedir. Serum kardiyak troponin düzeylerinin STYMI hastalarında, mortalite üzerine etkisini değerlendiren bir çalışmada, çalışmamıza benzer şekilde, artmış kardiyak troponin düzeyleri hastane içi mortalite ile ilişkilendirilmiştir [27]. Başka bir çalışmada da yüksek troponin düzeyleri hem kısa hem de uzun dönemde artmış mortalite ile ilişkili bulunmuştur [28]. Mevcut çalışmamızda ise, troponin düzeyi ile kısa dönem mortalite arasında anlamlı bir ilişki saptanmadı. Bu durum, çalışmamıza daha az sayıda hasta alınması, birinci aydan sonra ölüm görülmemesi gibi nedenlerden kaynaklanıyor olabilir.

Çalışmamızın küçük örneklemden oluşması ve hiperkalsemik hastaların bulunmaması önemli bir kısıtlamadır. Ayrıca sadece başvuru esnasındaki serum kalsiyum düzeylerinin değerlendirilmiş olması, dinamik kalsiyum değişiklerinin analiz edilmemesi, diğer bir çalışma sınırlamasıdır. Nutrisyonel durumun değerlendirilememiş olması ve kalsiyum düzeylerini etkileyebilecek $D$ vitamini düzeylerinin istenmemesi sonuçları değiştirebilecek önemli bir kısıtlamadır.

Sonuç olarak, AKS hastalarında düşük kalsiyum düzeyleri, hastane içi mortalite ve hasta içi komplikasyonlarla ilişkili olmamakla birlikte, AKS sonrası ilk bir ay içinde gelişen tüm nedenlere bağlı ölümlerde önemli bir etken olabilir. Serum kardiyak troponin ve ürik asit düzeyleri ise, hastane içi mortalite ile ilişkilidir. Kalsiyumun kardiyovasküler hastalıklardaki rolünün ve altta yatan mekanizmaların daha iyi belirlenebilmesi için, çok merkezli, geniş popülasyonlu, randomize, kontrollü ve prospektif çalışmalara ihtiyaç vardır.

Çıkar ilişkisi: Yazarlar herhangi bir çıkar çatışması olmadığını beyan etmektedir.

\section{Kaynaklar}

1. O'Gara PT, Kushner FG, Ascheim DD, et al. American College of Cardiology Foundation/American Heart Association Task Force on Practice Guidelines. 2013 ACCF/AHA guideline for the management of ST-elevation myocardial infarction: a report of the American College of Cardiology Foundation/American Heart Association Task Force on Practice Guidelines. Circulation 2013;127:362-425. https://doi.org/10.1161/ CIR.0b013e3182742cf6

2. Yu T, Jiao Y, Song J, et al. Hospital mortality in acute coronary syndrome: adjustment of GRACE score by D-dimer enables a more accurate prediction in a prospective cohort study. BMC Cardiovasc Disord 2019;19:252. https://doi.org/10.1186/s12872019-1239-4 
3. Kraft MD. Phosphorus and calcium: a review for the adult nutrition support clinician. Nutr Clin Pract 2015;30:2133. https://doi.org/10.1177/0884533614565251

4. Berridge MJ. Calcium signalling remodelling and disease. Biochem Soc Trans 2012;40:297-309. https:// doi.org/10.1042/BST20110766

5. Lind L, Jakobsson $S$, Lithell $H$, Wengle $B$, Ljunghall $S$. Relation of serum calcium concentration to metabolic risk factors for cardiovascular disease. BMJ 1988;297:960963. https://doi.org/10.1136/bmj.297.6654.960

6. Lind L, Skarfors E, Berglund L, Lithell H, Ljunghall S. Serum calcium: a new, independent, prospective risk factor for myocardial infarction in middle-aged men followed for 18 years. J Clin Epidemiol 1997;50:967973. https://doi.org/10.1016/s0895-4356(97)00104-2

7. Larsson TE, Olauson H, Hagstrom E, et al. Conjoint effects of serum calcium and phosphate on risk of total, cardiovascular, and noncardiovascular mortality in the community. Arterioscler Thromb Vasc Biol 2010;30:333339. https://doi.org/10.1161/ATVBAHA.109.196675

8. Payne RB, Little AJ, Williams RB, Milner JR. Interpretation of serum calcium in patients with abnormal serum proteins. Br Med J 1973;4:643-646. https://doi.org/10.1136/bmj.4.5893.643

9. Roffi M, Patrono C, Collet JP, et al. 2015 ESC Guidelines for the management of acute coronary syndromes in patients presenting without persistent ST-segment elevation of the European Society of Cardiology (ESC). Eur Heart J 2016;37:267-315. https://doi.org/10.1093/ eurheartj/ehv320

10. Ibanez B, James S, Agewall S, et al. 2017 ESC Guidelines for the management of acute myocardial infarction in patients presenting with ST-segment elevation: The Task Force for the management of acute myocardial infarction in patients presenting with ST-segment elevation of the European Society of Cardiology (ESC). Eur Heart J 2018;39:119-177. https://doi.org/10.1093/eurheartj/ehx393

11. Wang M, Yan S, Peng Y, Shi $Y$, Tsauo JY, Chen M. Serum calcium levels correlates with coronary artery disease outcomes. Open Med 2020;15:1128-1136. https://doi.org/10.1515/med-2020-0154

12. Hastbacka J, Pettila V. Prevalence and predictive value of ionized hypocalcemia among critically ill patients. Acta Anaesthesiol Scand 2003;47:1264-1269. https:// doi.org/10.1046/j.1399-6576.2003.00236.x

13. Choi YC, Hwang SY. The value of initial ionized calcium as a predictor of mortality and triage tool in adult trauma patients. J Korean Med Sci 2008;23:700-705. https:// doi.org/10.3346/jkms.2008.23.4.700

14. Shiyovich $A$, Plakht $Y$, Gilutz $H$. Serum calcium levels independently predict in-hospital mortality in patients with acute myocardial infarction. Nutr Metab Cardiovasc Dis 2018;28:510-516. https://doi.org/10.1016/j. numecd.2018.01.013
15. Lu X, Wang $\mathrm{Y}$, Meng $\mathrm{H}$, et al. Association of admission serum calcium levels and in-hospital mortality in patients with acute ST-elevated myocardial infarction: an eightyear, single-center study in China. PLoS One 2014;9:e99895. https://doi.org/10.1371/journal. pone.0099895

16. Michaëlsson $\mathrm{K}$, Melhus $\mathrm{H}$, Warensjö Lemming $\mathrm{E}$, Wolk A, Byberg L. Long-term calcium intake and rates of all cause and cardiovascular mortality: communitybased prospective longitudinal cohort study. BMJ 2013;346:228. https://doi.org/10.1136/bmj.f228

17. Zhang $\mathrm{Z}$, Chen $\mathrm{K}, \mathrm{Ni} \mathrm{H}$. Calcium supplementation improves clinical outcome in intensive care unit patients: a propensity score matched analysis of a large clinical database MIMIC-II. SpringerPlus 2015;4:594601. https://doi.org/10.1186/s40064-015-1387-7

18. Polo JCG, Ferrera CF, Pizarro VR, et al. P5477 Usefu Iness of hypocalcemia at admission as a prognostic $\mathrm{m}$ arker in patients with acute coronary syndromes. Eur Heart J 2019;40:ehz746.0431 https://doi.org/10.1093/ eurheartj/ehz746.0431

19. Jiang $M$, Yang $B$, Zhang $G$, Wang $H$. Effects of hypocalcemia on prognosis of patientswith ST-segment elevation acute myocardial infarction and nursing observation. Int J Clin Exp Med 2018;11:9762-9767.

20. GuX, Ding X, Sun $\mathrm{H}$, et al. Usefulness of Serum Calcium in the Risk Stratification of Midterm Mortality among Patients with Acute Coronary Syndrome. Biomed Res Int 2019;2019:1-9. https://doi.org/10.1155/2019/9542054

21. Magnoni $M$, Berteotti $M$, Ceriotti $F$, et al. Serum uric acid on admission predicts in-hospital mortality in patients with acute coronary syndrome. Int J Cardiol 2017:240:25-29. https://doi.org/10.1016/j. ijcard.2017.04.027

22. Ndrepepa G, Braun S, Haase HU, et al. Prognostic value of uric acid in patients with acute coronary syndromes. Am J Cardiol 2012;109:1260-1265. https:// doi.org/10.1016/j.amjcard.2011.12.018

23. Borghi C, Rosei EA, Bardin T, et al. Serum uric acid and the risk of cardiovascular and renal disease. J Hypertens 2015;33:1729-1741. https://doi.org/10.1097/ HJH.0000000000000701

24. Iseki K, Ikemiya Y, Inoue T, Iseki C, Kinjo K, Takishita $S$. Significance of hyperuricemia as a risk factor for developing ESRD in a screened cohort, Am J Kidney Dis 2004;44:642-650.

25. Dehghan A, van Hoek M, Sijbrands EJ, Hofman A, Witteman JC. High serum uric acid as a novel risk factor for type 2 diabetes. Diabetes Care 2008;31:361362. https://doi.org/10.2337/dc07-1276

26. Shankar A, Klein R, Klein BE, Nieto FJ. The association between serum uric acid level and long-term incidence of hypertension: population-based cohort study. J Hum Hypertens 2006;20:937-945. https://doi.org/10.1038/ sj.jhh.1002095 
27. Wanamaker BL, Seth MM, Sukul D, et al. Relationship between troponin on presentation and in-hospital mortality in patients with ST-segmentelevation myocardial infarction undergoing primary percutaneous coronary intervention. J Am Heart Assoc 2019;8:e013551. https://doi.org/1010.1161/ JAHA.119.013551

28. Ottani F, Galvani M, Nicolini FA, et al. Elevated cardiac troponin levels predict the risk of adverse outcome in patients with acute coronary syndromes. Am Heart J 2000;140:917-927. https://doi.org/10.1067/ mhj.2000.111107

Etik kurul onayı: Pamukkale Üniversitesi Tıp Fakültesi, Girişimsel Olmayan Klinik Araştırmalar Etik Kurulu'nun 06.02.2017 tarih ve E-8889 sayısı ile etik onay alınmıştır.

\section{Yazarların makaleye olan katkıları}

G.S. ve D.D. çalışmanın ana fikrini ve hipotezini kurgulamışlardır. G.S. ve D.D. teoriyi geliştirmiş, gereç ve yöntem bölümünü düzenlemişlerdir. Sonuçlar kısmındaki verilerin değerlendirmesini G.S., M.K.A. ve D.D. yapmışlardır. Makalenin tartışma bölümü M.K.A. ve G.S. tarafından yazıımış, D.D. ve M.K.A. gözden geçirip gerekli düzeltmeleri yapmış ve onaylamıştır. Ayrıca tüm yazarlar çalışmanın tamamını tartışmış ve son halini onaylamıştır. 